
opportunity to build up the supply of power
which would enable development to take place.

The total world consumption of power in the year 1950 was some 30,000 million kilowatt-hours. On a United Nations estimate of the annual rate of increase of power consumption at $3 t$ per cent the year A.D. 2000 would see a three-fold increase on the present demand for power. This must be met very largely from nuclear energy, for by that time coal and oil outputs would be well past their peaks and hydroelectric power would be approaching its full development. It should be noted that the present methods of generating electric power, by means of a thermal cycle, were inherently wasteful, nearly four-fifths of the available heat being rejected. If this rate of loss should continue the world would in fifty years' time be wasting heat in the production of electricity at a level in excess of twice the present total world consumption of power.

Referring to engineering as a career and to the present shortage of engineering graduates, Prof. Say drew a comparison between the situation in the
U.S.S.R. and in Britain. It was worth noting that despite the scale of the Russian need for engineers and scientists there was no extreme specialization in science in the secondary schools. In the U.S.S.R. the three final years of school, to age seventeen, included the study of physics, chemistry and mathematics for about 40 per cent of the time, and this held for all pupils, arts as well as science. Thus potential arts men had to pass examinations in science subjects while potential engineers and scientists had to study literary subjects to a level quite beyond that of the average British technical student.

The concluding section of Prof. Say's address was concerned with the ultimate values in human life and the possible threat which was offered by the pressure and strain of a mechanistic age to the qualities of imagination and creation which were key elements in the human make-up. "We cannot deny," he said, "that the threat exists, nor on the other hand that industrialization has brought great benefits to mankind. It will bring more, but only if the mastery remains where it belongs-in the care of the human spirit."
J. GREIG

\title{
NATURAL HISTORY OF THE FOX SQUIRREL
}

\begin{abstract}
A
FIELD study of the fox squirrel (Sciurus niger) in the south-eastern coastal area of the United States has been made by J. C. Moore (Bull. Amer. Mus. Nat. Hist., 13, Art. 1). The fox squirrel has probably diminished greatly in numbers and range because of changes wrought by man. Sciurus niger shermani was investigated in the sand hills of north Florida in a fir-maintained plant community which is common over a wide area of the south-eastern coastal plain, the Pinus australis-Quercus laevis associates. This plant community was changed suddenly and radically from a tall but very open forest of primeval long-leaf pines with turkey oak indifferently represented as a secondary, lower level dominant, to a virtually pure stand of turkey oak, relatively close-ranked and low.

Moore's inquiry was designed to determine how this large tree squirrel, after presumably evolving in the open stands of large pines, lives now in the lowly oak forest which has succeeded the logged-off pine.

The principal predatory enemies of Stiurus niger shermani are apparently the bold eagle, the red-
\end{abstract}

tailed hawk, and man. There are few suitable refuges for so large a tree squirrel in this low, open forest of deciduous trees and this may have brought about the following developments in behaviour unusual for a tree squirrel : a fairly well-established tendency for it to take refuge, when hard pressed, in the burrows of gopher tortoises underground; the use by the fox squirrels of hollows that extend down through the tops of old stumps to nesting chambers underground ; an escape behaviour, which may have developed since the removal of the old pines and which is presumed to be employed only against man, that involves hiding in the top of a second-growth long-leaf pine by ascending the plume-like apical twig so that the twig bends over horizontally under the squirrel, and the squirrel lies on top hidden from all below ; there is, apparently, an excessive number of leaf-nests per individual squirrel, thus providing more refuge.

While these forms of behaviour have survival value, they do not enable the animal to prosper.

\section{THE BRITISH COUNCIL}

HE annual report of the British Council for
$1956-57$ refers briefly to the review of Overseas
Information Services made by Dr. C. Hill. The
decisions recorded in the White Paper accepted about
nine-tenths of the Council's proposals for increased
activities and the Council specially welcome the
reference to co-operation with people and interests
outside the Government. The Council's work depends
largely on the help and advice of many educational,
professional, scientific and industrial bodies as well as
of thousands of individuals. About half the report
deals with the Council and the sciences and an
increasing proportion of the Council's work consists
of making known British scientific achievement,
assisting the dissemination of information to the
appropriate specialists and in serving as a link
between British experts and professional bodies and their opposite numbers abroad. Allied to this is assistance in training. Since 1950, the number of overseas students in the United Kingdom has risen from 10,000 to nearly 35,000 , about a third of whom are at universities or university colleges, while 60 per cent are concerned with the sciences. By far the largest increase in students is among those attending technical colleges, and the numbers might be greater still if their countries could find the necessary funds or Britain could offer scholarships and places on the scale of some of her competitors.

The report stresses Britain's advantage, shared with the Commonwealth and the United States, in the establishment of the English language among scientists as an essential means of communication, and the Council's work in furthering the study of English is thus of importance in this connexion. The 